\title{
Résidence du Corpus Troporum
}

Centre d'études médiévales, Auxerre, 19-23 octobre 2005

\section{Gunilla Iversen}

\section{(2) OpenEdition}

12 Journals

\section{Édition électronique}

URL : https://journals.openedition.org/cem/780

DOI : $10.4000 /$ cem. 780

ISSN : 1954-3093

Éditeur

Centre d'études médiévales Saint-Germain d'Auxerre

Édition imprimée

Date de publication : 15 août 2005

ISSN : 1623-5770

Référence électronique

Gunilla Iversen, "Résidence du Corpus Troporum », Bulletin du centre d'études médiévales d'Auxerre | BUCEMA [En ligne], 9 | 2005, mis en ligne le 03 novembre 2006, consulté le 22 septembre 2022. URL http://journals.openedition.org/cem/780 ; DOI : https://doi.org/10.4000/cem.780

Ce document a été généré automatiquement le 22 septembre 2022.

\section{c) (†)(2)}

Creative Commons - Attribution - Pas d'Utilisation Commerciale - Partage dans les Mêmes Conditions 4.0 International - CC BY-NC-SA 4.0

https://creativecommons.org/licenses/by-nc-sa/4.0/ 


\section{Résidence du Corpus Troporum}

Centre d'études médiévales, Auxerre, 19-23 octobre 2005

\section{Gunilla Iversen}

1 Les membres du Corpus Troporum, animé depuis des années par Gunilla Iversen (Stockholm), sont invités en résidence au Centre d'études médiévales d'Auxerre. Ce court séjour est destiné à mettre au point la publication du projet Sapientia- eloquentia. Il a été demandé au groupe d'organiser une journée sur les séquences et tropes de dédicace d'église (dimanche 23 octobre 2005).

Presentation of the research project Corpus Troporum

2 The research project Corpus Troporum (formerly "Projektet Troper") has been working since 1970 providing text editions of tropes to the chants of the medieval mass 900-1200. The project, for a long time supported by the Swedish Research Council, and has mainly been carried on by Ritva Jacobsson, Gunilla Björkvall and Gunilla Iversen.

3 During the coming years the following volumes are planned to be published: Bodil Asketorp's edition of tropes to the dedication, Ritva Jacobsson's edition of the tropes to the Saints and Gunilla Björkvall's edition of the offertory prosulae. Gunilla Iversen will hopefully be able to continue the work on the edition of the tropes to Gloria in excelsis and their interpretation.

4 Within the project a large number of articles has been published, several research meetings and a series of ESF (European Science Foundation) conferences have been arranged by the Corpus Troporum project. The Corpus Troporum archive of books, articles and micro-films is now housed in two parts of the newly combined Department of French, Italian and Classical Languages, Stockholm University, and will hopefully remain as a resource for us and for our colleagues from all over the world.

Editions

5 CORPUS TROPORUM I. Tropes du propre de la messe 1. Cycle de Noël, éd. R. JONSSON et alii, Stockholm, 1975 (Acta Universitatis Stockholmiensis, Studia Latina Stockholmiensia [= SLS] 21).

6 CORPUS TROPORUM II. Prosules de la messe 1. Tropes de l'Alleluia, éd. O. MARCUSSON, Stockholm, 1976 SLS 22). 

K. JOHANSSON, Stockholm, 1998.

Collected studies Stockholm, 1983. Forschung, hrsg. Von G. SILAGI, München, 1985. Troporum, Stockholm, 1986 (SLS 29). G. Björkval, Stockholm, 1993 (SLS 36).

Editions in preparation

Prosules de l'offertoire, éd. G. BJöRKVALL.

Tropes du Gloria in excelsis, éd. G. IVERSEN. scholastic Cultures in Medieval Europe
CORPUS TROPORUM III. Tropes du propre de la messe 2. Cycle de Pâques, édition critique des textes par G. BJÖRKVALL, G. IVERSEN, R. JONSSON, Stockholm, 1982 (SLS 25).

CORPUS TROPORUM IV. Tropes de l'Agnus Dei, édition critique suivie d'une étude analytique par G. IVERSEN, Stockholm, 1980 (SLS 26).

CORPUS TROPORUM V. Les deux tropaires d'Apt mss. 17 et 18, inventaire analytique des mss. et édition des textes uniques par G. BJÖRKVALL, Stockholm, 1986 (SLS 32).

CORPUS TROPORUM VI. Prosules de la messe 2. Les prosules limousines de Wolfenbüttel, édition critique des prosules d'Alleluia du ms.Wolfenbüttel, Herzog August Bibliothek Cod. Guelf. 79 Gud. Lat. par E. ODELMAN, Stockholm, 1986 (SLS 31).

CORPUS TROPORUM VII. Tropes de l'ordinaire de la messe. Tropes du Sanctus. Introduction et édition critique par G. IVERSEN, SLS 34. Stockholm, 1990 (SLS 34).

CORPUS TROPORUM IX. The Tropes for the Feasts of the Blessed Virgin, éd. A.-

Research on Tropes. Proceedings of a Symposium Organized by the Royal Academy of Literature, History, and Antiquities and the Corpus Troporum (June 1-3, 1981, Kungl. Vitterhets, Historie och Antikvitets Akademien. Konferenser 8), ed. G. IVERSEN,

Liturgische Tropen. Referate zweier Colloquien des "Corpus Troporum" in München (1983) und Canterbury (1984). Münchener Beiträge zur Mediävistik und Renaissance-

Pax et Sapientia. Studies in Text and Music of Liturgical Tropes and Sequences. Corpus

La tradizione dei tropi liturgici. Atti dei convegni sui tropi liturgici (Parigi, 1985- Perugia, 1987) organizzati del Corpus Troporum sull'auspicio della ESF, Centro italiano di studi sull'alto medioevo di Spoleto, ed. E. MENESTO, C. LEONARDI, Firenze, 1990.

Recherches nouvelles sur les tropes liturgiques. Recueil d'études réunies par W. Arlt,

Tropes for the Dedication of a Church. Edition of text and music by B. ASKETORP.

Tropes des fêtes des saints et de la croix, éd. R. JACOBSSON.

Sapientia-eloquentia. Studies on the Function of liturgical Poetry in monastic and

The Sapientia-project is based at the Department of Classical Languages at Stockholm University since 2001. The work is carried out by scholars from Stockholm University and Södertörn University College in close collaboration with scholars from the École Pratique des Hautes Études (Sorbonne) in Paris, Cambridge University and British Library, Medieval Institute at Leeds University, and Copenhagen University. The project is related to already existing international and Nordic research networks: Cantus Planus; FIDEM (Fédération Internationale d'Instituts d'Études Médiévales) ; the 
Ritual-project at the Center for Kultur og Kristendom, in projects financed by NorFA (Nordic Academy for Advanced Study), and Norsis.

The Aim of the Project

\section{Major publications in preparation within the Sapientia-project} Prothemata et Liber primus. A Critical Edition with an Introduction and a Translation, Studia Latina Stockholmiensia, SU (Doctoral dissertation).

34 E. KIHLMAN, Medieval Sequence Commentaries. Introduction and Edition of Commentaries and Prologues, Studia Latina Stockholmiensia, SU (Doctoral dissertation, forthcoming). Sapientia-eloquentia. Meaning and Function in Latin Poetry in the Middle Ages.

A joint volume with the final studies by all the members of the project to be published by Brepols.

37 La Parole chantée, a joint volume still in progress, prepared by M.-N. COLETTE, G. IVERSEN to be published in the series Témoins de notre historie, éd. P. BOURGAIN (Brepols).

38 A Compact Disc with examples of the text and music from the works studied in the project is planned to be made. The recording will make this poetry available for a larger audience.

Sequences and tropes for the Dedication of a Church 
39 Departing, basically, from material treated in the Sapientia volume we will discuss some examples of tropes and sequences for the Dedication of a Church in manuscripts related to places such as Compiègne, Limoges and Moissac, with participation of MarieNoël Colette and Gunilla Iversen, and eventually Bodil Asketorp who is preparing an edition of the tropes.

Dramatic representational forms used in the performance of the dedication will be discussed by prof. Nils-Holger Petersen.

41 Interventions by other scholars in the Sapientia-group, and our French colleagues.

42 (Among liturgical poetry to be treated are the tropes Divinus succendat amor, Concinat en plectrum, Gloria Flos laudis, and the sequences: Rex celice, Letetur et concrepet, Quam dilecta, Rex Salomon)

INDEX

Mots-clés : trope, poésie liturgique 